\title{
Potensi sektor pertanian dan perkebunan Kabupaten Pasaman Barat untuk menghadapi pasar bebas asean
}

\section{RELSAS YOGICA}

Jurusan Biologi, Fakultas Matematika dan Ilmu Pengetahuan Alam, Universitas Negeri Padang

E-mail: relsasyogica.1103992@gmail.com

\begin{abstract}
ABSTRAK
Dalam rangka mewujudkan visi 2020 ASEAN akan diterapkan pasar tunggal untuk wilayah Asia Tenggara. Pasar tunggal ini akan membentuk jalur bebas barang, jasa, tenaga kerja dan investasi. Sebagai anggota ASEAN, Indonesia tentu saja akan ikut serta dalam proses ini. Dalam rangka memperkuat integritas Indonesia dibutuhkan dasar perekonomian yang kuat, tentu saja ini didukung penuh oleh potensi unggulan daerah.Kabupaten Pasaman Barat merupakan salah satu wilayah pertanian dan perkebunan di Sumatera Barat.Komoditas unggulan Pasaman Barat adalah kelapa sawit, jagung, padi, pisang dan ubi jalar.Makalah ini membahas tentang potensi Kabupaten Pasaman Barat dari sektor komoditas unggulan pertanian dan perkebunan. Diharapkan dengan pembahasan yang telah dibuat maka akan diketahui secara lebih jelas mengenai potensi pertanian dan perkebunan Pasaman Barat untuk dapat dikembangkan demi keikutsertaan masyarakat daerah menghadapi pasar bebas ASEAN.
\end{abstract}

Key words: pasar bebas, perkebunan, pertanian, potensi

\section{Pendahuluan}

Pasar bebas di wilayah Asia Tenggara merupakan salah satu visi ASEAN 2020 yang ditetapkan pada KTT ASEAN ke-2 di Malaysia, dengan adanya pasar bebas ini maka akan terbentuk sebuah pasar tunggal di Asia Tenggara yang menyediakan jalur bebas untuk arus barang, jasa, tenaga kerja dan investasi ${ }^{[1]}$. Pasar bebas ASEAN akan terlaksana pada tahun 2015, lebih cepat dari tahun yang direncanakan awalnya yaitu 2020, tujuannya adalah untuk memperkuat daya saing ASEAN dalam menghadapi kompetisi global khususnya dengan China dan India.Keuntungan yang diharapkan adalah keseimbangan sektor perekonomian negara-negara anggota.Dalam pelaksanaan pasar bebas, terdapat 12 sektor yang menjadi prioritas liberalisasi. Sektorsektor tersebut adalah produk pertanian, angkutan udara, otomotif, e-ASEAN, elektronik, perikanan, kesehatan, produk karet, tekstil, pariwisata, produk kayu dan jasa $\operatorname{logistik}^{[1]}$.

Sebagai salah satu negara ASEAN, Indonesia tidak akan lepas dari proses ini. Indonesia akan menjadi salah satu negara
ASEAN yang menerapkan perdagangan bebas, oleh karena itu Indonesia dituntut untuk mempersiapkan diri dalam beberapa sektor potensial. Tahun 2007 telah dibuat kartu skor yang bertujuan untuk menghitung angka kesiapan negara ASEAN dalam menghadapi pasar bebas. Pada periode 1 Januari 2008 sampai 30 September 2009, sekretariat ASEAN melaporkan kesiapan Indonesia menghadapi pasar bebas ASEAN berdasarkan kartu skor tersebut adalah $80,37 \%{ }^{[1]}$. Angka ini dibawah Myanmar (85,05\%), Vietnam $(88,13 \%)$ dan Singapura $(93,52 \%)$.

Sebagai negara agraris, Indonesia mempunyai sektor unggulan untuk menguasai pasar bebas ASEAN yaitu sektor pertanian, kayu dan kulit ${ }^{[3]}$. Bahkan pada bidang obatobatan tradisional, Presiden Direktur Sidomuncul menegaskan bahwa Indonesia jauh lebih siap dibandingkan Malaysia, Vietnam dan Thailand $^{[4]}$. Kementerian Pertanian mengemukakan bahwa produksi komoditas pangan strategis dalam empat tahun terakhir umumnya menunjukkan kinerja yang baik seperti produksi padi mengalami peningkatan rata-rata 2,6 persen per tahun dari 64,4 juta ton gabah kering gilingpada 2009 menjadi 71,29 
juta ton gabah kering giling pada 2013. Produksi jagung juga meningkat rata-rata 1,39 persen per tahun dari 17,63 juta ton jagung pipilan kering tahun 2009 menjadi 18,51 juta ton tahun 2013.

Indonesia memiliki potensi yang bagus untuk bidang pertanian dan perkebunan, hal ini tentu saja didukung oleh daerah-daerah sentra.Salah satu daerah tersebut adalah Kabupaten Pasaman Barat, Sumatera Barat.Pasaman Barat terletak $175 \mathrm{~km}$ ke arah utara pusat kota Provinsi, Padang ${ }^{[2]}$. Pasaman Barat memiliki 11 kecamatan dengan luas daratan total adalah $3.887,77 \mathrm{~km}^{2}$ atau sekitar 9,29\% total wilayah Provinsi Sumatera Barat, dan luas lautan total adalah $800,47 \mathrm{~km}^{2}$ dengan panjang garis pantai $152 \mathrm{~km}$. Bentukan wilayahnya bergelombang dengan beberapa bukit dan gunung, ketinggian wilayah juga bervariasi dari 0mdpl sampai $2.912 \mathrm{mdpl}$. Kondisi wilayah yang seperti ini mendukung banyak sektor kehidupan masyarakat, termasuksektor pertanian dan perkebunan. Sektor ini diharapkan berperan dalam memperkuat integritas Indonesia dalam pasar bebas ASEAN 2015 dengan carameningkatkan kualitas diri melalui penguasaan teknologi dan meningkatkan produksi barang atau jasa dengan memperhatikan efektifitas dan efisiensinya. Tujuannya adalah agar produk yang dihasilkan menjadi salah satu produk yang diminati di pasar ASEAN.

Berdasarkan penjelasan di atas, maka penulis merasa tertarik untuk menyajikan makalah mengenai potensi sektor kehidupan masyarakat Pasaman Barat untuk menghadapi pasar bebas ASEAN.Dalam makalah ini dibatasi pada sektor pertanian dan perkebunan unggulan, yaitu sawit, jagung, padi, pisang dan ubi jalar.Komoditas unggulan yang dimaksud dalam makalah ini adalah komoditas yang memiliki nilai produksi tinggi dan ketersediaan lahan yang cukup. Sebagai bahan penunjang juga akan dibahas mengenai geografis, kependudukan dan kesempatan investasi di Pasaman Barat. Diharapkan dengan adanya kajian ini maka juga akan memberikan gambaran dan peluang investasi pada masa yang akan datang.

\section{BAHAN DAN METODE}

Penulisan makalah ini menggunakan pendekatan penelitian deskriptif dengan sumber data primer.Data primer merupakan data yang diperoleh langsung dari pihak pertama, data ini bersifat masa lampau dan tidak dilakukan perlakuan khusus terhadap variabel yang diamati.Metode yang digunakan dalam pengumpulan data adalah studi literatur.Tahapan pengumpulan dan penyajian data makalah adalah:

1. menemukan informasi mengenai kondisi wilayah Pasaman Barat,

2. menemukan informasi mengenai kehidupan sektor pertanian dan perkebunan masyarakat Pasaman Barat melalui situs pemerintah kabupaten yaitu www.pasamanbarat.com,

3. mengoleksi informasi yang dibutuhkan,

4. memilih 5 komoditas pertanian dan perkebunan unggulan masyarakat,

5. menyajikan dalam bentuk tabel hasil yang telah diperoleh.

Metode pemilihan sampel penulisan makalah ini adalah dengan teknik purposive sampling.Penulis memiliki tujuan untuk menambah nilai daerah Pasaman Barat dari sektor pertanian dan perkebunan kepada masyarakat Indonesia khususnya dan masyarakat dunia pada umumnya.

\section{HASIL DAN PEMBAHASAN}

\section{A. Geografi}

Kabupaten Pasaman Barat merupakan salah satu kabupaten di Provinsi Sumatera Barat yang lahir pada 7 Januari 2004 berdasarkan UU No.38 tahun 2003.Pasaman Barat memiliki luas wilayah yang cukup besar yakni lebih dari $9 \%$ luas wilayah provinsi, dengan bentuk permukaan tanah yang bergelombang. Jarak kabupaten dari Kota Padang adalah 180 $\mathrm{km}$.Pasaman Barat memiliki pantai sepanjang 
$152 \mathrm{~km}$ dan deretan pegunungan bukit barisan, dua gunung terbesar adalah Gunung Talamau dan Gunung Pasaman.Pasaman Barat terletak pada $00^{\circ} 33^{\prime \prime} \mathrm{LU}$ - 00¹1 LS dan 99¹0" BT $100^{\circ} 04$ BT. Batas wilayah bagian utara adalah Kabupaten Mandailing Natal, bagian selatan adalah Kabupaten Pasaman dan Kabupaten Agam, bagian barat adalah Samudera Hindia dan bagian timur adalah Kabupaten Pasaman ${ }^{[2]}$.Kabupaten Pasaman Barat memiliki 11 kecamatan yang berperan sebagai pusat beberapa komoditas.

Letak dan kondisi tanah akan memberikan keuntungan bagi masyarakat Pasaman Barat. Sektor perikanan dan pariwisata dapat dikembangkan dengan cepat dan mudah karena berbatasan langsung dengan Samudera Hindia.Kondisi tanah yang berada disekitar pegunungan dapat digunakan secara baik untuk sektor pertanian dan perkebunan, karena menyediakan tekstur yang pas dan mineral yang cukup untuk berbagai komoditas pangan maupun komoditas ekspor.Ketersediaan lahan cukup luas untuk dapat dikembangkan.

\section{B. Kependudukan}

Penduduk di Pasaman Barat memiliki keanekaragaman suku dan pekerjaan yang berbeda.Kabupaten ini memiliki penduduk yang sebagian berasal dari Kabupaten Pasaman, mengingat bahwa Kabupaten Pasaman Barat hasil pemekaran Kabupaten Pasaman tahun 2004.Pertumbuhan penduduk berdasarkan data dari BPS 2010 mengalami peningkatan sebesar $3 \%$. Penduduk berasal dari suku berbeda dengan pekerjaan yang yang beranekaragam pula. Suku-suku yang ada di Pasaman Barat antara lain adalah minang, jawa, batak dan mandahiling. Pekerjaan yang dikerjakan antara lain adalah bertani, berkebun, pegawai negeri sipil dan pegawai pemerintahan dan masih ada pekerjaan lainnya.

Lahan yang mendukung untuk mengembangkan sektor pertanian dan perkebunan membuat penduduk mengarahkan usaha ke arah pertanian dan perkebunan, termasuk pegawai negeri sipil dan pegawai pemerintahan. Saat pagi mereka bekerja di kantor, kemudian sore harinya bekerja di lahan. Beberapa juga memberikan upah kepada orang lain untuk mengurus lahan yang mereka punya. Pada tahun ini, petaniPasaman Barat mewakili Provinsi Sumatera Barat ke kompetisi tingkat nasional pada sektor tanaman jeruk, holtikultura, sayur dan tanaman hias ${ }^{[5]}$. Ini merupakan suatu kesempatan promosi yang luas bagi sektor pertanian dan perkebunan, dan juga membuktikan bahwa selain sektor unggulan yang dikelola masyarakat juga ada tanaman pertanian dan perkebunan lain yang patut untuk diperhitungkan secara global.Contohnya jeruk tersebut, tahun 2011 perkebunan jeruk mengalami kemunduran drastis karena kerusakan lahan oleh banjir dan rusaknya batang karena virus. Namun pada tahun 2014 ini pemerintah kembali menggiatkan penanaman jeruk, usaha yang dilakukan pemerintah salah satunya adalah pemberian bibit jeruk unggul sebanyak 12.000 batang kepada petani disertai dengan pelatihan pengelolaan perkebunan jeruk.

\section{Komoditas pertanian dan perkebunan unggulan}

Produksi pertanian dan perkebunan masyarakat antara lain adalah sawit, jagung, padi, pisang, ubi jalar, jeruk, pepaya, kelapa, nilam dan beberapa jenis kayu. Komoditas unggulan daerah adalah sawit, jagung, padi, pisang dan ubi jalar dengan sebaran produksi ada pada 11 kecamatan, yaitu Kecamatan Talamau, Pasaman, Luhak Nan Duo, Sasak Ranah Pasisie, Kinali, Gunung Tuleh, Sungai Aua, Lembah Melintang, Koto Balingka, Sungai Beremas dan Ranah Batahan.

1. Sawit

Perkebunan sawit di Pasaman Barat memiliki luas lahan 150.785 Ha pada tahun 2013. Lahan ini menghasilkan 222.489 ton sawit pada tahun yang sama dengan angka produktivitasnya adalah 1,4. Sekitar $80 \%$ masyarakat menggantungkan hidupnya pada sektor perkebunan yang luasnya mencapai 39\% luas kabupaten $^{[2]}$, namun sebagian besar masyarakat 
hanya berperan sebagai pekerja di perkebunan dan bukan sebagai pemilik. Produksi sawit di Pasaman Barat pada tahun 2013 jika dibandingkan dengan tahun sebelumnya mengalami peningkatan, pada tahun 2012 hasil produksi sawit adalah 114.619 ton. Perkebunan sawit di Pasaman Barat dikendalikan oleh pihak swasta dalam kapasitas makro dan mikro dan juga BUMN (PTP).Di Kecamatan Gunung Tulehterdapat pabrik pengolahan sawit.

Perkebunan sawit di Pasaman Barat dapat dikelompokkan pada usia tua yang nyaris tidak produktif lagi, sehingga membutuhkan peremajaan. Hal ini sudah dilakukan pada beberapa tahun terakhir di beberapa pusat perkebunan PTPN VI Ophir.Minyak sawit merupakan barang ekspor utama Indonesia ke ASEAN dan dunia ${ }^{[1]}$, ini dapat menjadi pertimbangan menarik investor untuk menanamkan kepercayaan pada perkebunan sawit di Indonesia umumnya dan Pasaman Barat khususnya.

2. Jagung

Luas pertanian jagung di Pasaman Barat pada tahun 2013 adalah $42.386 \mathrm{Ha}(10 \%$ luas kabupaten) dengan hasil produksi pada tahun tersebut adalah 290.344 ton. Hampir 70\% jagung yang ada di Sumatera Barat berasal dari Kabupaten Pasaman Barat.Lahan untuk pertanian jagung bagi masyarakat Pasaman Barat sebagian tidak disediakan secara khusus. Masyarakat menanam jagung dengan diselingi tanaman lain, seperti sawit, karet, pepaya atau beberapa jenis tanaman sayur. Lahan yang dikelilingi oleh perkebunan sawit memiliki hama yang merusak pertanian jagung, yaitu kera dan babi hutan. Hama ini menyerang pada saat usia jagung masih muda, bahkan pada lahan yang cukup luas hama babi hutan membuat sarang di tengan lahan. Berbagai upaya dilakukan masyarakat untuk mengatasi hama pertanian jagung mereka, antara lain adalah memasang perangkap disekeliling lahan dan melakukan pengawasan rutin.Teknik penanaman juga masih didominasi teknik tradisional.
Pemerintah kabupaten terus memperhatikan mengenai pertanian jagung ini.Berdasarkan data dari antarasumbar.news diperoleh informasi bahwa pemerintah melakukan sekolah lapangan pertanian teknologi terpadu (SLPTT) kepada 40 unit kelompok tani yang mewakili setidaknya $1000 \mathrm{Ha}$ lahan jagung.Tujuan kegiatan ini adalah untuk meningkatkan mutu petani jagung dalam pengelolaan pertanian, mulai dari pemilihan bibit, pemupukan sampai kepada pemanenan.Hasil pertanian jagung juga masih dalam bentuk barang belum jadi, ini merupakan kesempatan investasi untuk pengolahan jagung menjadi barang siap jadi, misalnya pop corn dan tepung.Dari segi luas lahan, pengembangannya mengarah kepada target 55.724 Ha pada tahun 2015 .

3. Padi

Luas pertanian padi pada tahun 2013 adalah $27.856 \mathrm{Ha}$ dengan hasil produksi pada lahan tersebut adalah 120.704 Ton. Angka produktivitas padi adalah 4,3.Target produksi padi adalah 5 ton per hektar setiap tahun, namun angka ini belum terpenuhi. Sekarang rata-rata hasil pertanian padi per hektarnya tiap tahun adalah 4,8 ton. Pemerintah Dinas Pertanian Tanaman Pangan Holtikultura dan Peternakan menyebutkan bahwa jika angka 5 ton per hektar tiap tahun itu tercapai, makaakan terbentuk masyarakat yang tahan pangan (swadaya pangan).

Padi yang ditanam di Kabupaten Pasaman Barat beraneka varietas.Salah satunya adalah padi gogo sigudang, padi yang dapat dikembangkan pada lahan kering.Berdasarkan SK Menteri No.5001/KPTS/Sr.120/2013, padi gogo sigudang yang berasal dari Pasaman Barat mendapatkan pengakuan dari menteri pertanian.Pertanian padi dari varietas ini merupakan peluang investasi yang cukup besar, mengingat sekarang sedang dilakukan peremajaan tanaman sawit.Jadi lahan tinggal bekas perkebunan sawit dapat digunakan untuk pengembangan jagung. 


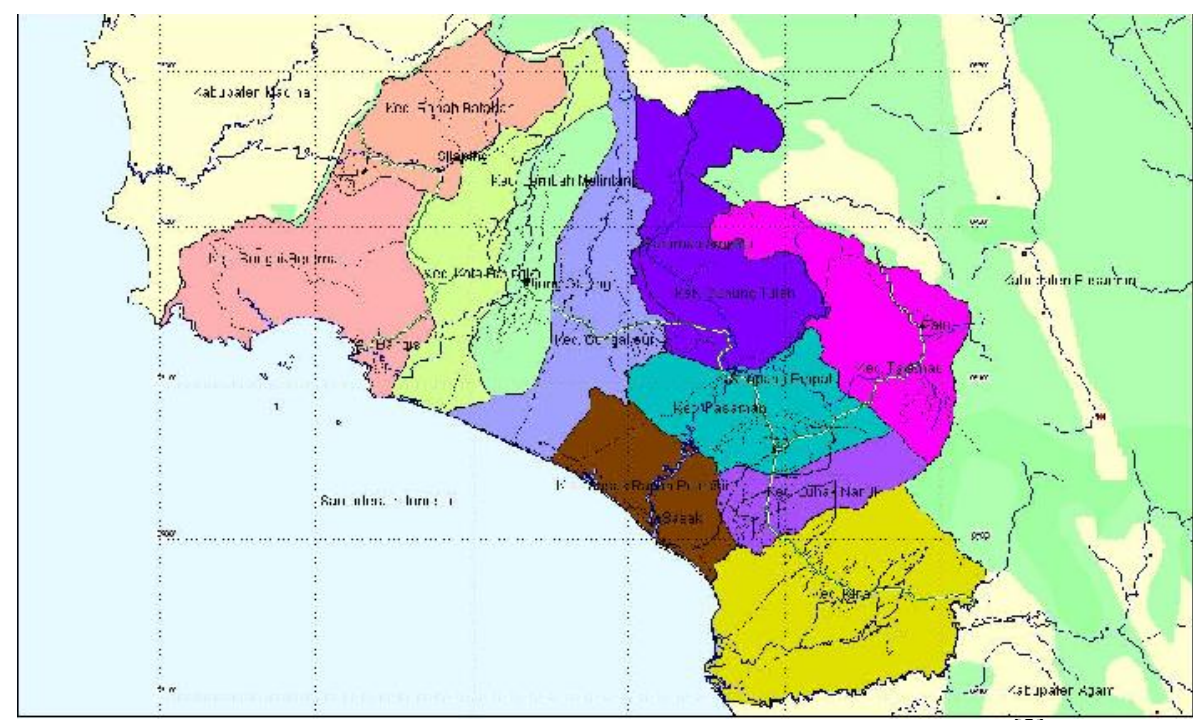

Gambar 1. Peta wilayah Kabupaten Pasaman Barat ${ }^{[2]}$

Tabel 1. Data luas lahan dan hasil produksi 5 komoditas di Pasaman Barat ${ }^{[2]}$

\begin{tabular}{|c|c|c|}
\hline \multirow{2}{*}{ Komoditas } & \multicolumn{2}{|c|}{2013} \\
\hline & Luas (Ha) & Hasil (Ton) \\
\hline Sawit & 150.785 & 222.489 \\
\hline Jagung & 42.386 & 290.344 \\
\hline Padi & 27.856 & 120.704 \\
\hline Pisang & 1.102 & 7.063 \\
\hline Ubi jalar & 254 & 8.123 \\
\hline
\end{tabular}

\section{Pisang}

Luas pertanian pisang di Pasaman Barat adalah $1.102 \mathrm{Ha}$ denga nilai produksi per tahun 2013 adalah 7.063 Ton. Angka produktivitasnya adalah 6,4. Kecamatan yang menjadi sentra produksi pisang di Kabupaten Pasaman Barat adalah Talamau (2.725 Ton), Koto Balingka $(1.363,78$ Ton $)$ dan Pasaman $(883,4$ Ton).Distribusi hasil pertanian pisang mengarah untuk luar provinsi dan dalam provinsi.Penanaman pisang tidak harus pada lahan khusus, bisa ditanam sebagai tumpang sari.

Pisang sebagai makanan penunjang yang memiliki kadar glukosa yang cukup tinggi merupakan tanaman berpotensi jual tinggi. Mengingat adanya ajakan pemerintah untuk menggunakan karbohidrat non beras, pisang dapat dijadikan sebagai salah satu pilihan.Pada tingkat internasional-pun pisang sudah mulai diperkenalkan. Pertengahan tahun ini, telah selesai diadakan kompetisi internasional pengolahan bahan makanan Indonesia, yang salah satunya adalah pisang ${ }^{[5]}$. PTPN VIII Subang pertama kali mengekspor pisang ke Singapura.Kegiatan ini merupakan usaha yang bagus untuk lebih memperkenalkan produk Indonesia kepada masyarakat internasional. Kabupaten Pasaman Barat sebagai bagian Indonesia akan turut mengambil peranan dalam hal ini. Peningkatan produksi komunitas pisang selain akan meningkatkan perekonomian masyarakat juga sebagai alat tangkap pasar lokal maupun internasional akan kebutuhan buah-buahan.

5. Ubi jalar

Pertanian ubi jalar menunjukkan nilai produtivitas yang cukup menarik, yaitu 31,9. Luas lahan yang lebih sempit jika dibandingkan dengan sektor unggulan lainnya yaitu $254 \mathrm{Ha}$, namun menghasilkan produk yang cukup banyak yaitu 8.123 Ton.Kecamatan yang menjadi sentra produksi ubi jalar di Pasaman Barat adalah Talamau (3.549 Ton) dan Ranah 
Batahan (2.660 Ton).Data yang diperoleh untuk luas tanaman ubi jalar ada perbedaan antara data dari Pemerintah Kabupaten Pasaman Barat dengan Badan Pusat Statistik.BPS menyebutkan bahwa pada tahun 2013 luas tanaman ubi jalar adalah 3.304 Ha.Perbedaan ini tidak harus dipermasalahkan karena nilai produksi masih cukup besar.

\section{Peluang investasi}

Banyak hal yang harus dipertimbangkan untuk melaukan investasi pada suatu daerah. Pertimbangan-pertimbangan ini lah yang sedang disiapkan oleh Kabupaten Pasaman Barat. Secara tidak langsung dampak yang akan muncul adalah semakin kuatnya integritas Indonesia dimata dunia. Penelitian dan pengembangan berbagai sektor masyarakan akan terus menambah nilai positif perekonomian masyarakat tersebut.

Pengembangan sektor pertanian dan perkebunan yang ada di Kabupaten Pasaman Barat terus diusahakan, seperti pemberian pelatihan pengelolaan lahan, pemilihan bibit tanam sampai kepada bagaimana cara mendistribusikan hasil. Sekarang ini investasi yang sedang diusahakan adalah pada sektor peternakan. Kabupaten Pasaman Barat membuka peluang investasi kepada Australia untuk melakukan pembibitan sapi dengan jumlah mencapai 400.000 ekor dengan kisaran dana mencapai 30 triliun rupiah.

\section{KESIMPULAN}

Dari hasil diatas dapat diambil beberapa kesimpulan sebagai berikut :

Pasaman barat merupakan kabupaten di Sumatera Barat yang terletak dibagian utara provinsi.Lahan yang dimiliki memiliki peluang besar untuk membantu integritas Indonesia menghadapi pasar bebas ASEAN.Potensi lahan yang ada menunjang kehidupan masyarakat pertanian dan perkebunan.Pengembangannya juga membutuhkan perhatian khusus oleh pemerintah, agar arah kemajuan dapat bernilai positif. Produksi unggulan yang dihasilkan dari sektor pertanian dan perkebunan adalah sawit, jagung, padi, pisang dan ubi jalar.

\section{DAFTAR PUSTAKA}

${ }^{[1]}$ Departemen Perdagangan Republik Indonesia.2014. Мепији Asean Economic Community 2015. Jakarta: Departemen Perdagangan Republik Indonesia.

${ }^{[2]}$ Dinas Pemerintah Kabupaten Pasaman Barat. 2014. Kabupaten Pasaman Barat (pasamanbarat.com). Diakses tanggal 13 Agustus 2014.

${ }^{[3]}$ Yogatama, Benediktus Krisna. 2014. Hadapi MEA 2015, ini sektor unggulan Indonesia (kontan.co.id).Diakses tanggal 12 Agustus 2014.

${ }^{[4]}$ Ramdan, Dadan M. 2014. Industri Jamu Tradisional Ketar Ketir Hadapi MEA (kontan.co.id). Diakses tanggal 12 Agustus 2014.

${ }^{[5]}$ Antara. 2014. Kabupaten Pasaman Barat (antarasumbar.news). Diakses tanggal 12 Agustus 2014. 